\title{
FOCUS
}

\section{ISLAM AND SUSTAINABLE DEVELOPMENT}

\author{
Mohammad Hashim Kamali*
}

\section{Introductory Remarks}

Islam's perspective on sustainable development arises from its vision of a moral economy and society, which may, in turn, be articulated into a structure of values and principles that are conducive to sustainability and growth. This would entail a coherent reading of the Islamic scripture as well as a number of Shar'iah concepts, such as the principle of public interest (maslahah), the higher purposes (maqasid) of Shar'iah, the divinely-ordained balance (mizan) in the created universe, and moderation (wasatiyyah). This last proscribes prodigality and waste in the use of resources, but more importantly, it seeks to inject moderation as an integral part of the personality and outlook of Muslim individuals and communities. Other principles that relate to our understanding of the Islamic perspective include that of Divine Oneness (tawhid), the vicegerency of humankind in the earth (khilafah), and justice (al-'adl).

Western liberal capitalism, which is based on the market economy, profit maximisation, and consumerism as a means for the pursuit of happiness, has failed people; 1 billion people now live in extreme poverty and the top 200 wealthy individuals have more income than the lowest 2.5 billion people. The Western model has also failed nature, since we are experiencing accelerated rates of extinction of species, loss of forests and ecosystems, and global warming. The scale and intensity of ecological degradation in the last five decades is unsurpassed in the history of humanity. The prevailing model of economic development has similarly created an artificial meaning for development and progress that has resulted in the collapse of financial markets on more than one occasion, promoted arms races and relied too heavily on fossil fuels. The capitalist economy, according to the Buddhist scholar, Anil Sakya, is subservient to 'the institution of unlimited desire.' This leads to competition, exploitation, human suffering, and social violence. ${ }^{1}$ 
From the Islamic perspective, the challenges of the twenty-first century are to a large extent a crisis of values. Questions are raised therefore over the foundations on which the entire structure of society is built. Emerging crises in economic, ecological and political relations are the natural outcome of the values and institutions that characterise modern civilisation. It is believed that through a thorough understanding of the social and ethical values of Islam, a creative approach to meeting those challenges of sustainability that currently confront humanity can be developed. ${ }^{2}$ The Islamic Declaration on Sustainable Development (IDSD) 2012 maintains that Islam's vision of economic development is entrenched in the ethical norms of Islam, which stress mankind's responsibility in the utilisation, allocation and preservation of natural resources, considered as gifts from God to the whole of humanity. The moral economy of Islam advocates, in turn, social justice, poverty eradication and protection of the planet's inhabitants and ecosystems. From its fusion of economic and moral principles, Islamic economics has proposed new strategies of growth, often involving an integration of Islamic values and the market economy which advocates a sustainable model of development. ${ }^{3}$

The overall understanding of sustainability and SD in the Islamic context has much in common with how they are understood in the mainstream literature, especially with regard to inter-generational equity and enhancement of the quality of life. Yet when SD is placed in the context of a capitalist economy and the hardline secularism of Enlightenment philosophy, which precludes the religious and spiritual dimensions of human existence, then Islam's viewpoints tend to differ from the capitalist understanding of SD.

Development becomes sustainable from the Islamic perspective when it is observant of equilibrium (mizan), moderation (wasatiyyah), and considerations of social equity. Mizan and wasatiyyah expound the two dimensions of the divinely-ordained balance in creation. Mizan is mainly concerned with the celestial universe and the place of planet earth in the grand scheme of creation, whereas wasatiyyah teaches moderation in all aspects of human conduct. Violation of mizan and extremism in human conduct amount to what the Qur'an describes in so many places as fasad (corruption and decay). It is caused by human aberrations and indulgence in extremism, including the sustained destruction of the earth's ecosystems, causing disturbances in the predicament of the earth itself, or senseless bloodshed and brutalities. All these are symptomatic of fasad striking its roots among human individuals and societies. Sustainable development under such conditions can at best be partial and deficient. Whereas some countries and communities are better placed and able to protect themselves from the vagaries of human transgression and fasad, the vast majority are unable to do so. 
This chapter is presented in six sections, along with a conclusion. It begins with a definition and brief history of sustainable development in the mainstream literature, setting the scene for an exposition of how this concept is understood in the Islamic context. The succeeding two sections then look at the notions of development in Islam, followed by a review of the Islamic blueprints for justice, moderation and worship. A question is also raised as to whether the earth's resources are finite or unlimited, and what Islam has to say on this. A separate section is devoted to an overview of Islam's teachings on Wisdom, Continuity and Change and how they contribute to a vision of sustainability and growth. The succeeding section reviews institutional arrangements conducive to SD in the Islamic texts and history. The last section looks into accountability for damage caused by the excesses of powerful individuals and companies from the viewpoint of Shar'iah. The chapter concludes with policy recommendations.

\section{Definition and History}

The concepts of sustainability and sustainable development (SD) have gained traction since the 1960s, due to heighted apprehensions over crucial issues of survival for the whole of humanity. The key question thus asked was: Are we moving towards a sustainable future considering the poverty trap, human dignity deficit, HIV/lethal diseases and ecological degradation?

In the 1970s, sustainability was used to describe an economy in equilibrium with basic ecological support systems. The three key components of SD included environmental, economic and social dimensions. However, other models viewed the environment (natural capital) as the overall foundation of the life-support systems for the planet's inhabitants.

The United Nations World Commission on Environment and Development released the report Our Common Future (1987), which included what is now one of the most widely recognised definitions of SD: "Sustainable development is development that meets the needs of the present without compromising the ability of future generations to meet their own needs." This was understood to mean taking note of both intra-generational equity (between rich and poor now) and inter-generational equity (between present and future generations) for a sustainable future. The International Union for Conservation of Nature (IUCN) added a new dimension to the understanding of SD by emphasising quality of life as an overall concept, in addition to the carrying capacity of supporting ecosystems. ${ }^{4} \mathrm{SD}$ is therefore evidently a long-term perspective, concerned with the interests and rights of future generations, as well as of people today. An inclusive approach to action, which recognises the need for all people to be involved in the decisions that affect their lives, is also implied. 
Searching questions have been raised, however, over an inherent ambiguity in the meaning of sustainability when it is asked: What are the needs of the present generation? For example, if any one of us were to list clean air as one such need, and then having to drive a car for transportation as another, is there not a conflict? Which would one choose or prefer, and is it realistic to raise the question in the first place? If one had to drive a long distance to get to work each day, would one be willing to move or get a new job to avoid polluting the air with one's exhaust fumes? What happens when a company's need for cheap labour conflicts with the workers' need for liveable wages? How do we decide whose needs are met? Poor or rich people? Citizens or immigrants? People living in cities or in the countryside? This generation or the next? When there has to be a trade-off, whose needs should go first? Many of the answers to these questions may seem to touch on conflicts of interest in the short term, at least. For example, industrial growth might conflict with preserving natural resources. Yet, in the long run, responsible use of natural resources now will certainly help ensure that there are resources available for sustained industrial growth far into the future. ${ }^{5}$

The emphasis in sustainability is thus on compromising various levels of needs and interests. An English dictionary defines compromise simply as 'settlement of a dispute by concessions on both or all sides.' Yet if the question is put in the context of liberal capitalism, human needs and greed are natural and every resource in this world is there for human consumption. Therefore, the most one can do is to 'compromise' one's natural greed. This certainly resonates with the kind of responses coming from the older traditions and religions, including Islam.

$\mathrm{SD}$ is a process, not a project or a product, since in the real world we deal with complex problems that need multiple solutions and perspectives. A variety of tools and concepts that support SD and offer solutions to its multifarious problems should be utilised. This is also reflective of the approach taken in this article: exploring a variety of ideas and principles in the Islamic tradition that relate to the theme of our enquiry.

$\mathrm{SD}$ in its Islamic context may be understood as a multi-dimensional process that seeks to strike a balance between economic and social development on the one hand, and the environment on the other. It asks that humans use resources in the best possible way, accounting for the environment upon which those resources depend. ${ }^{6}$ The alarming environmental degradation humanity is currently witnessing is due mostly to the human factors of greed, exploitation and domination. The ethical dimension is, therefore, fundamental to a comprehensive understanding of Sustainable Development.

Development in Islam is not necessarily linked to accumulation of wealth and living in luxury, but rather to conserving those human, social and natural capitals which are considered as necessities (daruriyyat). Progress and pursuit of 
happiness are tied to adding value to life through good deeds and knowledge as part of the human role in the building of planet earth. This would entail helping others in the spirit of ihsan, building a strong family unit, living a lifestyle of moderation that avoids waste and over-consumption (israf, tabdhir). ${ }^{7}$

Islam's identification of itself as din al-fitrah is also indicative of an outlook of harmony with a God-ordained nature, people and the environment. Din alfitrah implies that the earth is created in a state of natural equilibrium, endowed with the resources and capacity to sustain its life forms when not overwhelmed by corruption and excess, and when distributional equity is observed. The Qur'an elevates and deepens the notion of aesthetic intelligence, bio-mimicry, and learning from nature. Science and technology must integrate the human factor and natural wisdom into a holistic outlook if they are to be conducive to sustainability.

The Islamic belief in Divine Oneness (tawhid) encourages the spirit of integration and togetherness in man and nature, and of a human fraternity in which individual action is guided by the wider concerns of unity for the common good. As an article of the Muslim faith, tawhid means human submission to God's will, which also evokes inner harmony of the self and the soul-focused integration of mind and heart at the centre of being.

The earth's bounty and natural resources (ni 'maat) are 'gifts from God.' Islam's theory of ownership maintains that the human owner of land is a mere manager and beneficiary thereof; real ownership rests with God, the Creator of this planet. All natural resources - land, water, air, fire (energy), forests, oceans, fish and wildlife - belong to the people. These are considered the right and joint property of the people. Every community and generation is to utilise the earth responsibly for their benefit, use it with modesty and consideration for the wellbeing of its other inhabitants, and pass it on to future generations in a better condition than that in which it was received.

Both the Qur'an and nature contain signs (ayat) that demonstrate and offer insights into how to nurture naturalistic intelligence, innovation and learning. The whole of creation, including our human selves, are a series of signs (cf., Q Fussilat, 41:53) that invite exploration, discovery and research. This means that scientific observation naturally leads to development and should be conducted in the context of a theo-centric vision of creation. Science and development in the Islamic perspective must also preserve the essence of our humanity.

There is a need to re-examine the fundamentals of the capitalist economic model to ensure social equity and harmony between nature, people and markets. What is important in this transformational vision is to strike harmony and balance between the lives of individuals, rather than viewing them as consumers who strive for material accumulation and wealth. Therefore, we have to reflect on our 
views and perceptions, and change the way we see and utilise the planet. We have to learn how to fix our desire in the first place, rather than compromise with our desires against others. ${ }^{8}$

The Caux Round Table and its other working partner agencies have reached similar conclusions from their deliberations, as follows:

'Sustainable Development will further demand activation of ethical perspectives, giving new scope to values-based consideration of personal meaning and rectitude in our lives. Sustainable Development must become second nature to us all. It will become our habitual behavior and a way of thinking about creation and our role in the future evolution of life systems, societies, and culture.'

\section{Islam and Development}

The question as to whether there is a concept of development in Islam finds a ready response in the Qur'anic concept of building the earth (i'mar al-ard). ${ }^{10}$ This is an integral part, in turn, of the vicegerency (khilafah) of man in the earth, also from the Qur'an, which subsumes two other themes - namely, the goals and purposes (maqasid) of Shar'iah, and considerations of public interest (maslahah).

In their capacity as vicegerents, humans are stewards and custodians of the earth, with a mission to build it and establish a just social order therein. Stewardship is inherently averse to exploitative consumerism, to wanton and careless degradation of the planet's resources to the intolerable levels we witness today. Embedded in the notion of vicegerency is also accountability and faithful rendering of trust. Khilafah is an honoured status signified by subjugation (taskheer) of the earth and its bounties to the benefit of humankind. ${ }^{11}$ Trustees of the earth are accountable to God and to their fellow humans for the faithful rendering of the trust placed upon them, based on a set of criteria expounded in the Shar'iah.

Developing the earth's resources is the theme of several dispensations in the Qur'an and hadith, in terms of making the earth a pleasant place to live, greening it and bringing out its beauty and its bounty for the benefit of all. The principal instrument for developing the earth's resources is productive labour. All ablebodied individuals are enjoined to work and earn a lawful living so that "God, His Messenger and the believers may see the fruits of their labour." 12 People are also asked to go about and explore the earth, its tracts and its regions, earn a living and become a source of benefit to themselves and their fellow humans. ${ }^{13}$ They are to cooperate in good and beneficial work that is free of transgression, hostility and $\sin .{ }^{14}$ 'Abd al-Rahman Ibn Khaldun's (d. 1406CE) idea of 'umran, or building 
a humane civilisation on the earth elaborates on the concept of $i$ 'mar al-ard. It marks it as a transition from a nomadic lifestyle to the building of cities, attention to arts and sciences, industries and professions, as well effective leadership roles that direct and control the various stages of progress in civilisation building. ${ }^{15}$

The higher goals and purposes of Shar'iah (maqasid al-Shar 'iah) are focused on the primacy of a set of essential purposes, or daruriyyat - namely, of life, faith, mind, property and family. These are evidently crucial to SD and provide the necessary context for it. Muslim individuals and their governments are dutybound to protect these values and also seize all available opportunities for their promotion and protection at all times. ${ }^{16}$

Protection and development of property (hifz al-mal), being one of the daruriyyat, is divided in turn into five sub-themes. These reflect on economic development through circulation (rawaj) of goods and services in the market place, justice ( $a d l$ ), and growth (tanmiyah) as important dimensions of hafz al$m a l .{ }^{17}$ There is supportive evidence in the sources to the effect that property should not remain idle and non-productive. It should be developed and utilised through the application of labour and capital, in all their beneficial combinations. ${ }^{18}$

Public interest (maslahah) is a valid basis of law and judgment in Shar'iah, as well as something governments should secure, as and when the opportunity arises. According to a legal maxim, "The affairs of the imam (head of state) are judged by reference to maslahah," which is self-evident on the primacy of public interest in all government activities and programmes. Maslahah is eminently developmental and looks into the prospects of improving the temporal and spiritual aspects of people's lives. Genuine public interest is that which brings the greatest good to the largest number without any compromise on basic principles. ${ }^{19}$

Every living creature, as the Qur'an says, is created from water, and the hadith guidelines on this add moderation in the use of water, even if it be for making a ritual ablution (wudu'). Further instructions found in hadith advise that the earth is green and beautiful - whoever plants a tree and looks after it until it matures and bears fruit is spiritually rewarded. If a Muslim plants a tree or sows a field, and humans, beasts and birds eat from it, all of it will be counted as charity from him. ${ }^{20}$ The Prophet, pbuh, further directed that at times of war, Muslim soldiers should not chop down trees or destroy agriculture or kill animals, unless it be for sustaining human life. According to yet another hadith, "even if the final hour arrives and one has a palm-shoot in one's hand and is able to plant it - one should plant it." ${ }^{21}$ Commenting on this, al-Qaradawi observed that this hadith underscores the merit of building the earth in its own right, even if it brings no benefit to the planter or anyone else - as there is little expectation of any benefit when the final hour has arrived. Namr Mustafa, who also quotes this hadith, adds the following episode: 'Ummarah bin Khuzaymah $b$. Thabit reported that he 
heard 'Umar ibn al-Khattab saying to his ('Ummarah's) father: "What is stopping you from planting your land?" Khuzayamah replied that he was an old man and could well die the next day. "Umar replied, "Let me help you plant it." 'Ummarah said that he then saw "Umar ibn al-Khattab planting trees in the land with his father.' ${ }^{22}$ The caliph, 'Umar ibn al-Khattab, evidently knew how to combine austerity and purity (zuhd) with 'imarat al-ard, and how this purpose could be gainfully pursued by realisation of the goodness of the earth through work. The austerity of zuhd stops one from indulging in benefits/pleasures more than one needs, which is confined for the most part to the person who practices it, whereas work for imarat al-ard benefits the community as a whole and carries greater spiritual reward than personal zuhd. ${ }^{23}$

The Islamic notion of what constitutes a good life is also underlined by sufficiency (kifayah), or that which draws mostly on the use of local resources and knowledge to attain a people-centred model of development of human capital and the earth's capabilities.

\section{Justice, Moderation and Worship}

Social justice (al-'adalah al-ijtima'iyyah) in Islamic law and scripture signifies equitable distribution of wealth and opportunities in society, regardless of race, colour and creed. It is something the government has a responsibility to ensure. There should, for example, be an assigned portion for the poor from the riches of the wealthy through the poor-due (zakah), in addition to other modes of distribution, such that extreme poverty and excessive wealth do not exist side by side. This is because the Qur'an declares that "the believers are brethren," and also that "wealth should not circulate only among the rich." ${ }^{24}$ Elsewhere the text also provides that "you shall not attain virtue unless you spend [on others] of that which you like for yourselves." 25 The juxtaposition in another place in the Qur'an of justice and beneficence ('adl wa ihsan) moderates justice with the spirit of liberality and fairness. ${ }^{26}$ This would justify the conclusion that individual and community action in the present should contemplate the general well-being of both present and future generations.

The rules of Shar'iah on obligatory and supererogatory charity (zakah and sadaqah), inheritance, and the public treasury (bayt al-mal) envisage a system of wealth redistribution designed to institutionalise distributive justice in an Islamic system of government. Note also that the assets of zakah and sadaqah are distributed among both the fuqara' (poor Muslims) and masakin (poor nonMuslims). ${ }^{27}$ According to the Islamic Declaration on SD, charity is every good deed that benefits people and takes care of the environment in which they live. It may be an act of social solidarity, a contribution to the restoration of peace and 
security, or an act towards the eradication of poverty and unemployment. This may be in a bid to achieve justice and equality through participation in the development enterprise, motivated by religious, cultural and humanitarian concerns. ${ }^{28}$

Furthermore, the concept of worship ( 'ibadah) in Islam is also comprehensive, such that it is not confined to ritual religious performances, but has important socio-economic underpinnings. Understood in its broader sense, 'ibadah also means acting with sincerity to fulfill all the injunctions of Islam that bring benefit to humanity. Doing so is tantamount to the essence of submission, which is central to all 'ibadah. For instance, when the Qur'an designates the believers as brethren and then orders them to "make peace among your brothers," ${ }^{29}$ acting on this injunction with the correct intention partakes in 'ibadah. Anyone who removes conflict and helps to bring peace to society will therefore be performing an act of worship. Similarly, when the Prophet said that "cleanliness is one-half of the faith - al-tuhur shatr al-iman," observing the purport of this hadith with correct intention also partakes in ibadah. One can add to this the effort one makes to uproot corruption (fasad) in government and in society, as well as the prevention of environmental degradation, all of which, when done with correct intention, partake in 'ibadah and contribute to the construction of a just society and civilisation.

The foregoing is substantiated by the detailed rules of Islamic law, or fiqh, to the effect that engagement in certain activities - such as the pursuit of beneficial knowledge, earning a lawful living to support oneself and one's family, acting as a judge and witness with the intention of serving the cause of justice - all partake in 'ibadah. Acting as a trustee in due discharge of one's responsibilities to protect and improve the earth's living environment for the benefit of its inhabitants is also to partake in worship.

\section{Resources of the Earth - Are They Unlimited?}

The question as to whether the earth's natural resources are sufficient to cater for the needs of its inhabitants has received two different responses, both of which find some support in the Islamic scripture. For instance, the Qur'an provides evidence to the effect that God is the true provider: "there is no moving creature in the earth but its sustenance depends on God." "30 This is supported by other passages, such as: "God is He Who gives all sustenance." ${ }^{31}$ Moreover, in a longer passage one reads that God sends down rain, which gives life to the earth and enables it to grow fruit and foodstuffs for "your sustenance." Likewise, God also subjugates to humans the sea, by which they travel and seek their sustenance, the sun and the moon, and outer space ${ }^{32}$ - "in heaven is your sustenance as [also] that which you were promised." ${ }^{33}$ These passages tend to relate the notion of 
sustenance to the means and the effort by which it is obtained. We shall not delve into the nuances of meanings conveyed in these verses, but suffice it to say that this evidence points to the conclusion that the earth's resources are Providential and, perhaps, interminable and abundant.

The other line of evidence found in the Qur'an points to the conclusion that the resources of planet earth are not unlimited. Thus, it is suggested that God Most High created everything in the earth in measured proportions, implying that the earth's resources are finite and that human action should consider this premise during the use and exploitation of those resources. Sometimes, however, both this and the above line of evidence are given in the same passage or verse, and then espoused with implied warnings that resource adequacy or depletion are not always under human control. To quote the Qur'an:

And there is not a thing of which We do not have (inexhaustible) treasures; but of which We only send down quantities in due and ascertainable measures. (al-Hijr, 15:21)

And We send down water from the sky duly measured, and We cause it to stay in the soil, or remove it and cause it to flow. (al-Mu'minun, 23:18)

God bestowed blessings on the earth and measured therein all things and their nourishment in due proportions. (Fussilat, 41:10)

One likely conclusion to be drawn from these two readings - and one that finds support from the totality of evidence in the scriptures - is that one reading is potential and the other actual, and the question of causality and means is also to be brought into the picture if one were to turn the potential into a tangible reality. Like all other aspects of human activity in agriculture, industry and science, the human agent turns the potential into actual through effort, labour, skill, and (even more so) science and technology.

It will be noted that the latter of the two readings - one of resource scarcity is the pressing reality and predicament affecting vast sections of humanity almost everywhere, and certainly in developing countries. ${ }^{34}$ The IDSD 2012 noted that food security is a real issue in most of the 57 OIC Member States, and particularly in those who have faced famine and food-related problems in the recent past. It also noted that the food and agriculture sectors offer key solutions for hunger and poverty eradication. For this to happen, however, there is a real need to increase scientific research and appropriate technological output, and for these to be made readily available to those who need them. Further research is also needed to 
ascertain safe uses of chemicals and insecticides. Reasonably priced GMO-free foods also need to be produced for an active and healthy life. ${ }^{35}$ The IDSD further highlighted the increased stress on fresh water resources, which may create crisis situations in vulnerable Member States, and emphasised the need to conclude fair and equitable agreements on the distribution of water resources among riparian countries. Energy sustainability issues and desertification, particularly in subSaharan African countries, were added to the list of challenging issues that call for innovative research on energy rationalisation and efficiency. To meet these daunting challenges will require collective and affirmative action by the UN and the international community. ${ }^{36}$

\section{Wisdom, Continuity and Change}

Wisdom (hikmah) is a Qur'anic concept that underscores the importance of making advice an integral part of practical living. This entails beneficial cooperation and exchange of views during the making of rational choices in one's personal life, within one's own community or beyond. Sustainability in the use and development of earth's resources certainly demands the pooling of the wisdom, skills and insight of all communities and nations, with their differential experiences of local and geographical characteristics. Hikmah in Islam teaches that human beings from all faiths and nations should learn from one another and exchange knowledge and wisdom to establish a better and more prosperous life on earth. Conviction backed up by action is the hallmark of hikmah, making it a way to avoid empty rhetoric. The Qur'an frequently directs the faithful to espouse their faith with right action, as in its recurrent phrase wa'lladhina amanu wa 'amilu al-salihat - those who have faith and do good works. Verbal affirmation alone is not enough unless it is backed up by necessary action.

Transforming society and the world economy into a sustainable entity, however, presents a momentous set of challenges to all of us. The challenge is unprecedented in scope and engulfs the safety and survival of all of the earth's inhabitants, as well as that of the planet itself. It requires a fundamental shift in consciousness and vision, leading to constructive individual and collective action. The magnitude of this challenge is such that no country or community alone can address it without collective cooperation and sharing of insights into how best to respond to it.

The fact that the basic structure of values in Islam is unchangeable and rooted in scripture is conducive to the sustainability of its core values, including the essentials of dogma and morality, respect for human life and dignity, commitment to impartial justice, private ownership and family values. These are known in the language of Shariah as the thawabit, in contradistinction to mutaghayyirat, 
which include formulas and principles that are liable to change over time, in response to changing circumstances. The mutaghayyirat are changeable through the modalities of ijtihad (independent interpretation), tajdid (renewal) and islah (reform, changing/improving the status quo), in tandem with the educational, cultural and other attainments of a humane civilisation. Hence, the basics of a SD paradigm appear to be verifiable within the structure of Islamic values. ${ }^{37}$

\section{Sustainable Development Institutions}

A number of resource management and welfare institutions were created during Islamic history and which contributed to sustainability objectives in the economy and society. These may be summarised as follows: ${ }^{38}$

1. Land reclamation or revival (ihya' al-mawat): any person who reclaims un-owned barren land by reviving, cultivating and putting it to beneficial use acquires it under the rules of Shar'iah and becomes its lawful owner. But ownership is contingent on reclamation and utilisation of the land within a specified time frame, failing which it can be re-possessed by the authorities. Ihya' gives people a powerful incentive to invest in sustainable uses of land in order to provide for themselves and contribute to the welfare of their family and community.

2. Land Reserves: The ruling authorities have the right (and obligation) to prevent the development of land by private individuals and agencies whenever such development would result in environmental damage or be otherwise injurious to general welfare. Government authorities may also reserve unowned land for public benefit purposes, or reserve it in order to remove public access to an indispensable resource.

3. Natural Reserves (hima): Wildlife and natural resources are protected under Shar'iah by zoning areas, called hima. In such places, industrial development, habitation, and extensive grazing are restricted or disallowed. The Prophet himself, followed by the early caliphs of Islam, established such hima zones as public property for common use by the community. Madinah became the first biosphere reserve in Islamic history when the Prophet declared it sacrosanct throughout the area between its two mountain paths. Its foliage was not to be consumed except for fodder. The game of Madinah was also protected against hunting and poaching.

Islam teaches that the species of the earth resemble human communities and deserve protection, which can be achieved through hima. This would support the building of 'national parks' and other sanctuaries for wildlife preservation and beauty-enhancement objectives. 
4. Zoning and land use planning (haram): This involves protecting water resources and other utilities, communal pastures and woodlands, and lands containing resources that are indispensable to a community's welfare objectives.

5. Public Land Grants (iqta'): Governments are authorised by Shar'iah to make iqta' grants of un-owned land to individuals and institutions for the purpose of reclamation and development. This may involve the granting of concessions for agriculture, horticulture, building etc., as well as the shifting of such developments to suitable locations, far away from unwanted localities.

6. Leased Lands (ijarah): The government is also authorised to institute the lease (ijarah) of state-owned lands, whether for reclamation purposes, the growing of needed crops, or the introduction of farming techniques based on the transfer of usufruct through leasing. This method may also be used for the purpose of renovating/structurally improving existing facilities and buildings, thereby combining aspects of the iqta' method with leasing (iqta' manfa'at al-ard or iqta' al-istighlal).

7. Charitable Endowment (waqf): Shar'iah encourages individual Muslims and institutions to participate in the conservation and sustainable development of land and natural resources through waqf, gifts, inheritance, and loans. Historically, waqf charitable endowments constituted a major source of financing for public welfare activities, including the building and upkeep of mosques, educational institutions and healthcare services. More recently, the waqf sector has been the focus of attention from the Islamic financing industry, which has turned the mostly illiquid and poorly managed waqf assets into viable investment vehicles. Waqf endowment funds set up by civil society and the private sector can also be used as effective tools for socio-economic development and environmental protection. Government authorities in many Muslim countries have introduced new guidelines for the proper management of waqf lands by ensuring the qualifications of their managers and safeguarding the benevolent objectives of waqf properties.

8. Market Inspector (muhtasib): Historically, many of the responsibilities of environmental care and protection fell under the jurisdiction of the hisbah, a government agency charged with eradication of harmful activities. The muhtasib, who headed this office, was to be knowledgeable in Shar'iah. $\mathrm{He} / \mathrm{she}$ was responsible for the inspection of markets, roads, buildings, watercourses, hima reserves and so forth. Included among his/her duties were the supervision and enforcement of safety regulations, hygiene, 
and cleanliness; removal and disposal of waste materials and pollutants; prevention and elimination of hazards and nuisances; protection of reserves from violation and trespass; and prevention of animal abuse. $\mathrm{He} /$ she was also responsible for assessing damage and imposing fines and other light penalties in order to ensure the proper upkeep of public welfare facilities. His/her jurisdiction was semi-executive and semi-judicial, standing somewhere between the police and the judge.

\section{Accountability and Compensation}

An overarching principle of Shar'iah which is relevant to sustainability is the compensation for damage caused through transgression and unlawful conduct. This is the subject of a legal maxim-cum-hadith, that "Harm may neither be inflicted nor reciprocated." 39 The right to benefit from essential resources such as water, forests, fish and wildlife, air and sunlight, is a shared right of all members of society. People are entitled to benefit from them in due proportion to their needs (and where needs are distinguished from wants). No one may deny this to others, but if anyone were to do so to an extent customarily considered intolerable, then according to the legal maxim before us, the victim would be liable for compensation. The injured party would be able to take legal action to seek compensation for the damage caused.

A number of supplementary legal maxims from Shar'iah that regulate the subject of harm (darar) include the following:

- A greater harm is eliminated by tolerating a lesser one.

- Harm may not be eliminated by its equivalent.

- Harm to an individual is tolerated in order to prevent harm to the general public.

- Harm is eliminated to whatever extent possible.

- A way out must be found when (intolerable) hardship occurs. ${ }^{40}$

\section{Conclusion}

The prevailing capitalist economic paradigm is premised on profit maximisation and consumerism. Making matters worse, the global media promotes exaggerated publicity, commercial advertising, and overconsumption. The scale and speed of consumption, dubbed as the 'great acceleration,' shows markedly increased water, food, and energy consumption patterns. Statistics from global and urban 
population centres show steep rises in the use of water, energy, cars, computers and electrical appliances from the latter half of twentieth century onwards.

A great deal of the environmental damage and industrial pollution the world has been witnessing is caused by the big multinationals. While writing these lines, I was struck by the news concerning the Volkswagen car maker, that its cars were fitted with software designed to cheat on emissions tests. The culprit should naturally be made to pay for its wrongdoing - not just in the context of Germany, but worldwide. This would be a fitting example for the application of those legal maxims of Shar'iah just reviewed.

The question remains, moreover, whether prosperity can be achieved without growth or an economy based on fossil fuel. In response, it may be said that transformation to a sustainable future requires reducing consumption, redirecting consumption to less destructive avenues, and learning new ecology transformation methods towards a low-carbon society and economy. ${ }^{41}$

It will be noted further that the schism between the spiritual and the 'scientific' was imported into the Muslim world along with the materialist industrial culture that effectively separated the political system from community traditions. The rapid introduction of industrialism into these countries, without regard for their local cultures and values, caused serious disruption. Globalisation and the borderless world of communication have not only condoned this trend, but also accelerated it by seeking to penetrate traditional cultural values. For Muslims, liberal capitalist values need to be scrutinised in light of the Islamic humanitarian approaches to justice $(a d l)$, beneficence (ihsan), family and community principles. Muslim scholars and community leaders need to resort to innovative thinking (ijtihad) and come up with rational sustainable solutions that transcend the prevailing liberal capitalist underpinnings of their economy and culture.

Islam is emphatic on the understanding that human beings have been given a special role as steward/khalifah for all creatures. This requires that people use their capabilities to bring about peace and well-being for all the inhabitants of this planet. A government that acts as steward to the people should be cognisant of the nature of this responsibility. For SD to become a reality, it is imperative that peace and security prevail; SD is not likely to thrive in a tense and conflictridden environment, such as the world has been witnessing in the aftermath of the September 2001 attacks.

It is further suggested that SD plans make space for people's religious aspirations. This is because SD can engage the individual as a moral agent who derives their sense of purpose and commitment from their religious beliefs. Religious leaders and teachers have a role to play in providing guidance on SD, in making it an integral part of their religious advice to the people. ${ }^{42}$ 
I now propose the following by way of actionable policy recommendations:

- SD is a holistic concept requiring a comprehensive approach to development and environmental issues, inclusive of ethical considerations, moderation and justice.

- No single country or community can be expected to offer all the required solutions to the challenges posed by SD. Credible and well-moderated regional and international agreements need to be signed on outstanding water issues, pollution control, deforestation etc., and must be implemented according to agreed upon schedules.

- There should be accountability for violation and damage inflicted. The principle of accountability should also be adopted in the regional and bilateral agreements referred to above. The Shar'iah positions and principles on this subject, reviewed above, merit consideration.

- The nation-state and its sovereignty-anchored perspectives have often been translated into narrow protectionist policies, focused on national interests. The changing times, however, often mean that issues are no longer confined to national and territorial borders. People are suffering, issues of pollution, inequality and violence are weighing heavily on human survival and the health of the planet earth. A transformational vision is needed, one which embraces a broader, fairer and more humanitarian approach to sustainability issues.

- The pooling of knowledge and the exchange of cultural and regional experiences among countries and communities needs to be facilitated through specific agreements and MoUs, signed between governments, ministries and those departments in charge of economic planning, science and environment. Common consultative positions on SD issues should be considered and adopted.

- SD presents a long-term challenge. Rapid results can only be expected with regards to certain specific issues. The larger issues of concern to the world economy, liberal capitalism, inter-generational equity and environmental degradation require carefully articulated plans, with specified targets and measurable progress.

- Last but not least, the individual is the vital moral agent and actor in all issues of concern to SD, especially with reference to moderation and the prudent management of resources. Everyone should take part, and a citizen awareness programme should be considered by both the media and education policy makers. 
For Muslims, it is imperative to consider Islamic teachings when searching for a new and more inclusive metric than GDP for measuring the progress of society. This new metric must also include happiness, family values, social learning, universal peace, green and clean economy for a wider understanding of sustainability and SD.

I conclude with the message conveyed by a Caux International Roundtable on Sustainable Development, held in Kuala Lumpur, 12-13 August 2015, and for which the present writer was present. A remarkable comment was included in the Roundtable Statement: modern physics and Relativity Theory inform us of the $4^{\text {th }}$ dimension, Time, which transcends classical Newtonian physics. Islam, it is believed, can provide a $5^{\text {th }}$ dimension for seeing new perspectives of life, like progress, justice, peace and sustainability, both for humans and nature. We all have a responsibility to evolve and co-create new models for the progress of humanity through purposeful efforts that enhance deep understanding, interpretation and application of ecology and culture.

\section{Notes}

* Mohammad Hashim Kamali, Founding CEO of IAIS Malaysia, graduated from Kabul University, and took his PhD in Islamic and Middle Eastern Law at the University of London in 1969. Professor Dr M. H. Kamali served as Professor of Islamic Law and Jurisprudence at the International Islamic University Malaysia (IIUM, 19852007), then Dean of the International Institute of Islamic Thought and Civilization (ISTAC). He also held Visiting Professorships at McGill University's Institute of Islamic Studies; Capital University, Ohio; and the Wissenschaftskolleg, Berlin. A member of the Constitution Review Commission of Afghanistan (2003), he has provided expert legal consultation to the new constitutions of Iraq, the Maldives and Somalia. Eminent authority on Islamic legal studies, he has published over 170 academic articles and 35 texts, including standard textbooks at universities worldwide. He can be contacted at ceo@iais.org.my.

1. Phra Shakyavongsvisuddhi (@Anil Sakya), "Sustainable Development in Context," Pegasus Newsletter of Caux Roundtable Network Vol V, Issue VIII (August 2015), 4.

2. Cf., Odeh Rashed al- Jayyousi "Re-thinking sustainability and progress: Islamic perspectives,"p.7. islam-science.net/re-thinking-sustainability-and-progress-islamicperspect (accessed 28 October 2015).

3. "Islamic Declaration on Sustainable Development, 2012," www.isesco.org.ma/ index.php?...islamic...islamic...sustainable-development (accessed 2 October 2015). The IDSD was adopted by the Environment Ministers of the 57 OIC Member States participating in the fifth Islamic Conference of Environment Ministers, held in Astana, Kazakhstan, on 18 May 2012. The IDSD has been adopted within the framework of the Islamic world's participation in the Rio+20 Summit.

4. Cf., Odeh Rashed al-Jayyousi, Islam and Sustainable Development: New Worldview 
http://www.gowerpublishing.com/isbn/9781409429012 (accessed 2 October 2015). See also https://www.ashgate.com/pdf/SamplePages/Islam-and-SustainableDevelopment-CH1.pdf (accessed 2 October 2015)

5. Anil Sakya, "Sustainable Development in Context," p. 6.

6. Cf., Muhammad Nouh, "Sustainable Development in a Muslim Context," www. earthcharterinaction.org/invent/.../11\%20Manuscrip Muhammad. (accessed 30 August 2015)

7. Jayyoussi, "Re-thinking sustainability and progress: Islamic perspectives,"p.10. (accessed 2 October 2015)

8. Cf., Anil Sakya, "Sustainable Development in Context," p.8.

9. As quoted in Sakya, ibid, p. 9.

10. Cf., Q Hud, 11:61.

11. Cf., Q Ibrahim, 14: 32.

12. Q al-Tawbah, 9:105

13. Q al-Mulk, 67:15.

14. Cf. Q al-Ma'idah, 5:2. See also for further details on the civilisational mission of Islam, Mohammad Hashim Kamali, "Maqasid, Ijtihad, and the Prospects of Civilisational Renewal," Islam and Civilisational Renewal Vol.2 (January 2011), 255f.

15. See for details on Ibn Khaldun's conception of 'Umran, Syed Farid Alatas, "Ibn Khaldun and the Good Madina", Islam and Civilisational Renewal, Vol. 4, no. 4 (October 2013), 529f. See in the same issue of this journal a Viewpoint by myself on the characteristic features of Islamic civilization, entitled "The Religious Thrust of Islamic Civilisation," pp.634-639.

16. See for details on maqasid al-Shariah, Mohammad Hashim Kamali, Shari'ah Law: An Introduction, Oxford: Oneworld Publication, 2008, ch. 6, pp.123-141.

17. The other two being stability (thubat), and clarity (wuduh) in transactions and exchange of goods and services among people.

18. See for details on the sub-themes of hifz al-mal, Muhammad al-Tahir ibn 'Ashur, Maqasid al-Shari'ah al-Islamiyyah, ed. Muhammad al-Tahir al-Messawi, Amman (Jordan): Dar al-Nafa'is, 2001/1421, pp. 464-475.

19. See for details on maslahah Mohammad Hashim Kamali, Principles of Islamic Jurisprudence, Cambridge: Islamic Texts Society, 2003, pp.351-369.

20. Cf., Muslim al-Nishapuri, Sahih Muslim, Kitab al-Musaqat, bab Fadl al-ghars wa'ldhar', hadith no. 1552. Namr Mustafa, Usul al-Nazar, vol I, 332.

21. Hadith narrated by Anas b Malik and recorded by al-Haythami, Majma' al-Zawa'id, bab Ayyu'l-Kasb-i Atyab, vol. 4, p.63. Also quoted in Mustafa, Usul al-Nazar, vol. I, 332 .

22. Al-Qaradawi, Kayfa Nata'amalu ma' al-Sunnah al-Nabawiyyah, p. 130; see also Mustafa, Usul al-Nazar, I, 343.

23. Mustafa, Usul al-Nazar, I, 344.

24. Q al-Hujurat, 49:10, and al-Hashr, 59:7 respectively.

25. Q Aal-'Imran, 3:92.

26. Q al-Nahl, 16:90.

27. See for detail on distributive justice Mohammad Hashim Kamali, Freedom, Equality and Justice in Islam, Cambridge: Islamic Texts Society, 2002, 133-142.

28. General Framework of Islamic Agenda for Sustainable Development: Islamic Declaration on Sustainable Development 220, background paper no.5 available at : 
http://scienceislam.net/article.php?id_article=261\&lang=fr

29. Q Yunus, 10:49; see also al-Anfal, 8: $\overline{1}$.

30. Q Hud, 11:6.

31. Q al-Dhariyat, 51:58.

32. Q Ibrahim, 14:32-33.

33. Q al-Dhariyat, 51:22.

34. This is also the view taken by Iyad Abumoghli in his article "Sustainable Development in Islamic Law" - http://waterwiki.net/images/8/85/Sustainable Development in Islamic Law - Iyad Abumoghli.doc. (accessed 2 October 2015)

35. Islamic Declaration on Sustainable Development 2012 : www.isesco.org.ma/index. php?...islamic...islamic...sustainable-developm...(accessed 2 October 2015).

36. Ibid.

37. See for details Mohammad Hashim Kamali, "Tajdid, Islah and Civilisational Renewal," Islam and Civilisational Renewal, vol. 4, no.4 (October 2013), 484-512.

38. See for details Mohammad Hashim Kamali, The Right to Life, Security, Privacy and Ownership in Islam, Cambridge: Islamic Texts Society, 2011, pp. 261 \& $274 \mathrm{f}$. See also Iyad Abumoghli "Sustainable Development in Islamic Law -" waterwiki. net/.../sustainable_Development_in_Islamic_Law_Iyad_Ambergholi. (accessed 2 October 2015).

39. The Mejelle (Art. 20). See also for fuller discussion of this maxim and illustrations Kamali, Shari'ah Law: An Introduction, $144 \mathrm{f}$.

40. See for further details on all the three maxims quoted Kamali, Shari'ah Law, 146-149.

41. Cf.,https://www.ashgate.com/pdf/SamplePages/Islam-and-SustainableDevelopment-CH1.pdf (accessed 2 October 2015).

42. These conclusions were also supported by the Caux International Roundtable held in Kuala Lumpur in 12-13 August 2015, in which the present writer participated. 